\title{
Anatomy of Subterranean Organs of Medicinally Used Cardueae and Related Species and its Value for Discrimination
}

\author{
Elisabeth FRITZ *, Johannes SAUKEL
}

Department of Pharmacognosy, University of Vienna, Althanstrasse 14, 1090, Vienna, Austria

* Corresponding author. E-mail: Elisabeth.Fritz@fritztec.com (E. Fritz)

Sci Pharm. 2011; 79: 157-174

doi:10.3797/scipharm.1010-05

Published: $\quad$ December $2^{\text {nd }} 2010$

Accepted: $\quad$ December $2^{\text {nd }} 2010$

Received: $\quad$ October $20^{\text {th }} 2010$

This article is available from: http://dx.doi.org/10.3797/scipharm.1010-05

(C) Fritz and Saukel et al.; licensee Österreichische Apotheker-Verlagsgesellschaft m. b. H., Vienna, Austria.

This is an Open Access article distributed under the terms of the Creative Commons Attribution License (http://creativecommons.org/licenses/by/3.0/), which permits unrestricted use, distribution, and reproduction in any medium, provided the original work is properly cited.

\begin{abstract}
Numerous species of the Asteraceae, the composites, are famous for their use in both traditional and conventional medicine. Reliable anatomical descriptions of these plants and of possible adulterations provide a basis for fast identification and cheap purity controls of respective medicinal drugs by means of light microscopy. Nevertheless, detailed comparative studies on root and rhizome anatomy of valuable as well as related inconsiderable composite plants are largely missing yet. The presented study aims to narrow this gap by performing anatomical analyses of roots and rhizomes of 16 species belonging to the tribe Cardueae, of formerly and currently used drugs as well as their near relatives as potential adulterations (Carlina acaulis L., Carlina vulgaris L., Arctium lappa L., Arctium tomentosum Mill., Carduus defloratus L., Carduus personata (L.) Jacq, Cirsium arvense (L.) Scop., Cirsium vulgare (Savi) Ten., Cirsium erisithales (Jacq.) Scop., Onopordum acanthium L., Silybum marianum (L.) Gaertn., Rhaponticum scariosum Lam., Centaurea jacea L., Centaurea scabiosa L., Centaurea cyanus L., Cnicus benedictus L.). A detailed verbal and graphical survey of the analysed anatomical features is provided. Several characters were finally extracted which allow for discrimination of the examined species and may be effectively used for drug quality controls.
\end{abstract}

\section{Keywords}

Root anatomy • Asteraceae • Microscopy • Plant anatomy 


\section{Introduction}

The Asteraceae represent one of the largest plant families comprising at least 23,000 species and about 1,600 genera [1]. Numerous composites such as Carlina acaulis, Arctium lappa and Taraxacum officinale, to mention only a few, have a long history in both traditional and conventional medicine. Light microscopy is a common and effective method for the identification of pharmaceutically useful plants and their adulterations. Hence, detailed knowledge of the anatomy of the diverse plant parts used as drugs is required for quality control. Yet, reliable comparative studies of the anatomy of subterranean organs of medicinally exploited Asteraceae species and their close relatives are rare. Most studies date back to about 1900 and concentrate on the secretory system of the family tribes Cardueae (characterized by resin ducts) and Cichorieae (laticifers) in particular [2-5]. Most work, however, concerned the aerial vegetative organs and did not aim to discriminate species. Some recent studies deal with the subterranean organ anatomy of diverse Asteraceae species [e.g. 6-11]. However, the investigated species were of no medicinal value and not of a Western European origin. An additional recent study concentrates on the secretory structures of the subterranean organs of various species of the tribe Cardueae and demonstrated - based on five identified types of secretory ducts - the value of anatomical characters for the discrimination of composite plants [12]:

- Secretory ducts of type SD1 and SD2a / SD2b are of schizogenous origin and distinguished based on the $\mathrm{C} 1: \mathrm{C} 2$-quotient (i.e. the length of the cells lining the ducts [C1] divided by the length of adjacent cells [C2], longitudinal section, see fig. 1 [fig cited: 12]).

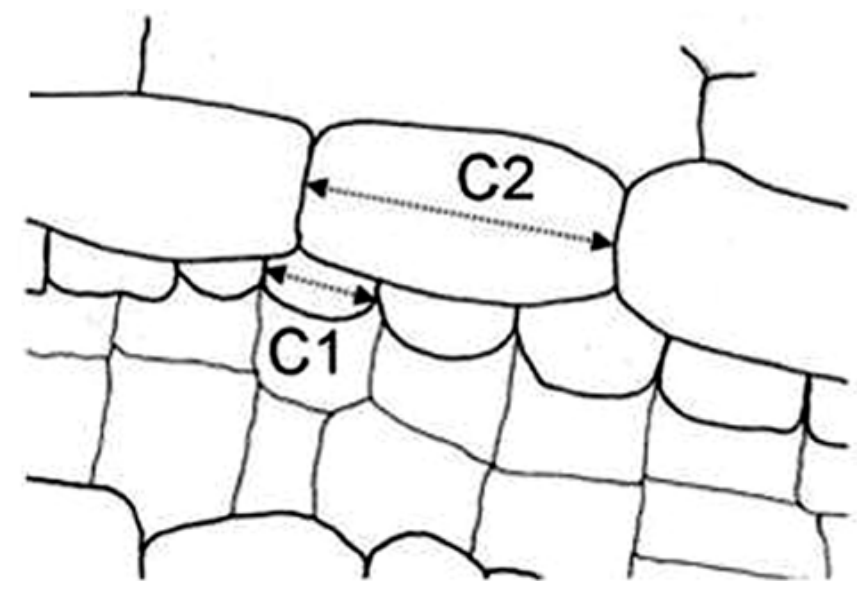

Fig. 1. Secretory duct in longitudinal section build from two adjacent layers of cells differing in length. The quotient $\mathrm{C} 1: \mathrm{C} 2$ is used to discriminate between three types of secretory ducts (fig. cited: [12]).

- Secretory ducts of type SD3 show cell lysis: the large lumen is filled with the remnants of the cells.

- Secretory ducts of type SD4 seem to be actually intercellular space, filled with diverse substances secreted by the adjacent parenchyma cells. 
Although the secretory system proofed valuable for species discrimination, the anatomy of entire roots and rhizomes is still insufficiently described. So far a single study only focuses on medicinal drugs [13] by comparing the root anatomy of Taraxacum spp., Leontodon sp., Aposeris foetida, and Hypochaeris sp..

In order to narrow this gap of knowledge, a comprehensive study on the anatomy of the subterranean organs of 32 genera and 57 species from the tribes Cardueae (22 species) and Cichorieae (35 species) used in medicine or occurring as potential adulterations was initiated. The anatomy of these plants was analysed in detail and a database of typical anatomical features created [14].

The present work deals with the tribe Cardueae and analyses the underground part anatomy of species possessing a taproot or dominating rhizome. Taxa with a fibrous root system were excluded. The focus thereby lies on formerly or currently medicinally used species of the Cardueae, which have been used for medical purposes since long:

Thus already Hieronymus Bock [15] mentions Carlina acaulis L. as a plant highly valued by people as a diaphoretic and diuretic medicine and against worms. The roots soaked in vinegar were also known as appropriate remedy against scabies and tetter [16]. Today, this plant is still used in traditional medicine and serves as an ingredient of various liquids such as Swedish bitters elixir, as a diuretic as well as a stomachic remedy and against skin diseases $[17,18]$.

Even though rarely used nowadays, another species of the genus Carlina, Carlina vulgaris L., still has a place in traditional medicine. The species is applied against nocturnal enuresis and to cure frightened babies [19].

The medicinally use of Arctium lappa L. reaches back to the ancient times. Dioskurides [20] praises the effects of its roots as an expectorans (the antitussive activity was confirmed by Kardošová [21]) and its application on luxations and sprains. Lonicerus [22] mentions its effects against asthma. The usage of $A$. lappa oil as hair restorer was first mentioned in 1673 [Pankovius, 1673 in: 23] and is still popular among people. In traditional medicine, A. lappa - along with Arctium tomentosum Mill. - is still valued as a plant with antirheumatic, diuretic and diaphoretic effects $[17,19]$. Recent studies document a gastroprotective activity [24] and hepatoprotective effects [25].

Although officinal in former times (Radix et Herba Spinae albae seu Cardui tomentosi; [23]), these days, Onopordum acanthium is no longer used except in anthroposophical medicine (Onopordi acanthi herba) [17]. The roots (together with the sap of the fresh leaves) were reported to be useful against stiff neck and opisthotonus [26, 20] and as a diaphoretic and laxative remedy [23].

Rhaponticum has been used in Chinese, Tibetan and Mongol medicine for more than 5,000 years [27]. Rhaponticum carthamoides (Willd.) Iljin. was studied currently as it is supposed to possess various positive effects on memory, blood, cardiovascular and nervous system and on physiological functions such as work capacity and sexual function (reviewed by Kokoska [28]). Łotocka \& Geszprych [27] dealt with the anatomy and secretory structures of $R$. carthamoides but the identification of the plant and its roots remained problematic as comparative material from other species of the genus is missing. 
On that account the anatomy of Rhaponticum scariosum Lam. - the only species of the genus native to Austria (the area mainly addressed here) - has been included in our studies. Though $R$. scariosum has been used in former times as substitute to Rheum palmatum [29] it is not applied any longer.

Carduus defloratus L., Carduus personata (L.) Jacq, Cirsium arvense (L.) Scop., Cirsium vulgare (Savi) Ten., Cirsium erisithales (Jacq.) Scop. Silybum marianum L., Centaurea jacea L., Centaurea scabiosa L., Centaurea cyanus and Cnicus benedictus L. have been examined as near relatives of the taxa mentioned above.

\section{Results}

Reliable anatomical root and rhizome characters discriminating between the various species investigated in this study were identified. These features are proofed valuable for the characterisation of the drugs and may be used for quality control:

The following main anatomical features of roots and rhizomes can be used for purity and quality control in pharmacy: the overall distribution and proportions of the principal tissues in transverse section, the fine structure of the cork, vessel types, the occurrence of fibers including their maximum diameter and wall structure, and, finally, the occurrence of sclereids and secretory ducts in diverse tissues.

Our studies demonstrated that even within one single plant the diameter of the largest vessels may differ largely depending on their position along the root axis. In transverse sections the dimension of the largest vessels of Silybum marianum, for instance, varied largely with their position along the taproot: the maximum diameter decreased from 245 $\mu \mathrm{m}$ near the tip of the root to $113 \mu \mathrm{m} 1.5 \mathrm{~cm}$ below the hypocotyle. However, in other samples of the same species this parameter varied insignificantly only.

The example of S. marianum points out that the diameter of vessels, though a popular feature used for quality control of drugs, has to be carefully considered as preparations of drugs usually are available as a cut formulation. Therefore, standardisation of the analysed root parts appears impossible.

For the purpose of standardization measured values given in the following microscopical descriptions always refer to a section of the root axis just below the hypocotyle (see Experimental). As the occurrence of secretory ducts is of particular importance for the taxonomic identification of the species described in the following, respective data have been included from [12].

\section{Microscopical descriptions and discriminative anatomical characters}

\section{Carlina acaulis L. (fig. 2)}

Secondary root: cork thin-walled; cortex durable or lost in course of rhytidome formation; endodermal resin ducts are in size a multiple of the diameter of the surrounding parenchyma cells, lost together with the cortex; secondary phloem dominant, comparable in extension to the vascular cylinder, with fibers arranged in bundles, rays with crystalline needles; secondary xylem consists of fibers and vessels; vessels reticulate and simple, strongly bordered, up to $114 \mu \mathrm{m}$ in diameter; medullary rays multiseriate, parenchymatous, 
with crystalline needles of the same type occurring in the phloem; secretory ducts of type SD1 and SD2a (average quotient $\mathbf{C 1 : C 2}<0,4$ [12]), size a multiple of the diameter of the surrounding parenchyma cells, located in the medullary rays and in the phloem rays; pith missing; sclereids missing;
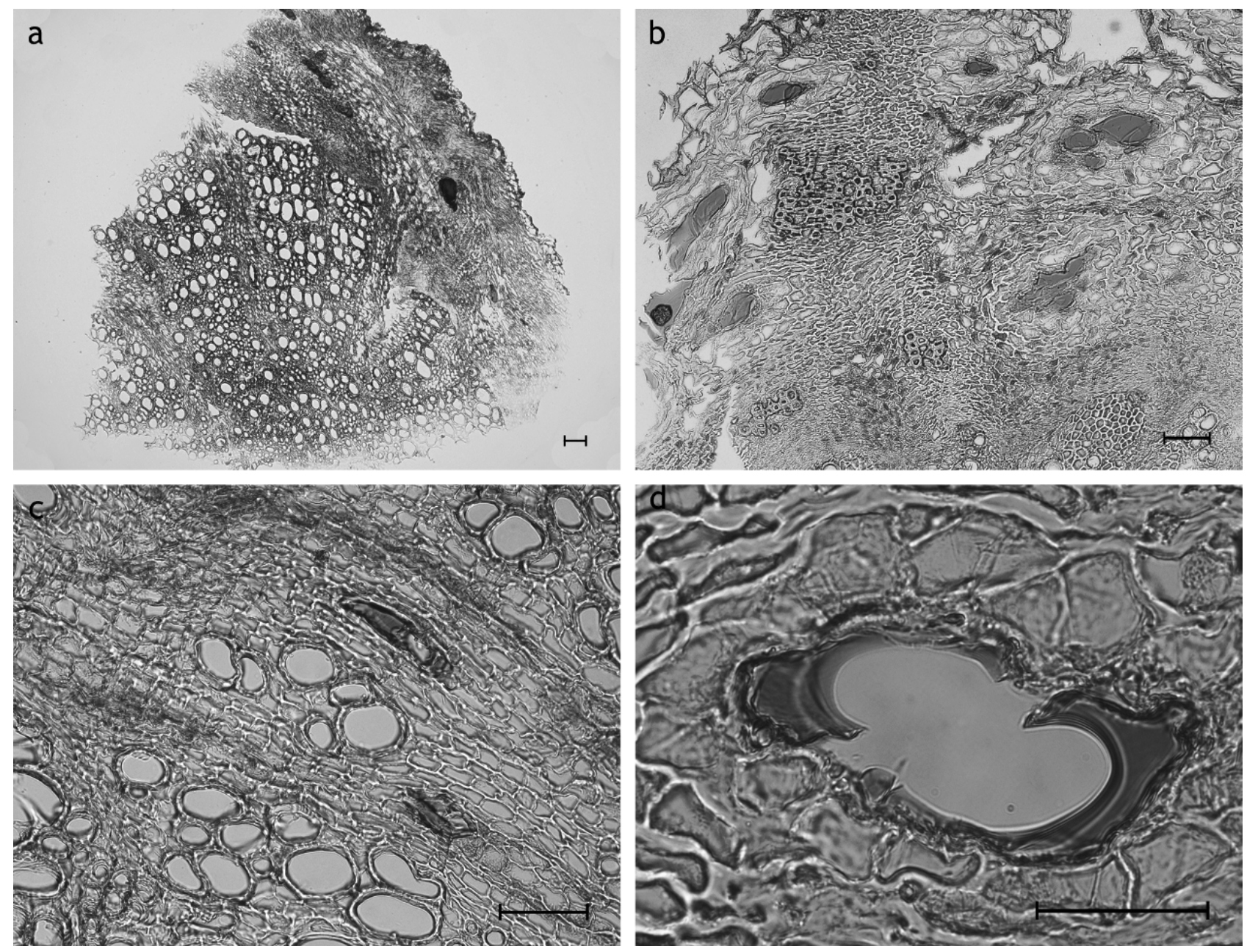

Fig. 2. Carlina acaulis root: a: Overview showing the extension and arrangement of the participating tissues: the secondary xylem is the most prominent component followed in extension by the secondary phloem; cortex conspicuously small or lost in course of rhytidome formation; small cortex with endodermal resin ducts, secondary phloem and xylem with secretory ducts type SD1 within the medullary rays; $b$ : secondary phloem having an expansion a multiple of the diameter of the surrounding parenchyma cells and with fibers arranged in bundles; c: SD1 and crystalline needles in medullary rays of the vascular cylinder; d: secretory ducts type SD1 of secondary phloem; a-d: transverse sections; scale bars are $50 \mu \mathrm{m}$

\section{Carlina vulgaris L. (fig. 3)}

Secondary root: cork thin-walled sometimes with crystalloids; cortex enduring; distinct endodermis with endodermal resin ducts - usually up to 10 surrounding cells at maximum; secondary phloem broad, but of lesser radial extension than the vascular cylinder, with 
secretory ducts of type SD2 (C1:C2 >0,48); secondary xylem dominated by fibers, few vessels dispersed over the transverse section, strongly bordered, up to $59 \mu \mathrm{m}$ in diameter; medullary rays biseriate; pith missing; sclereids, laticifers missing; fibers in secondary phloem missing;
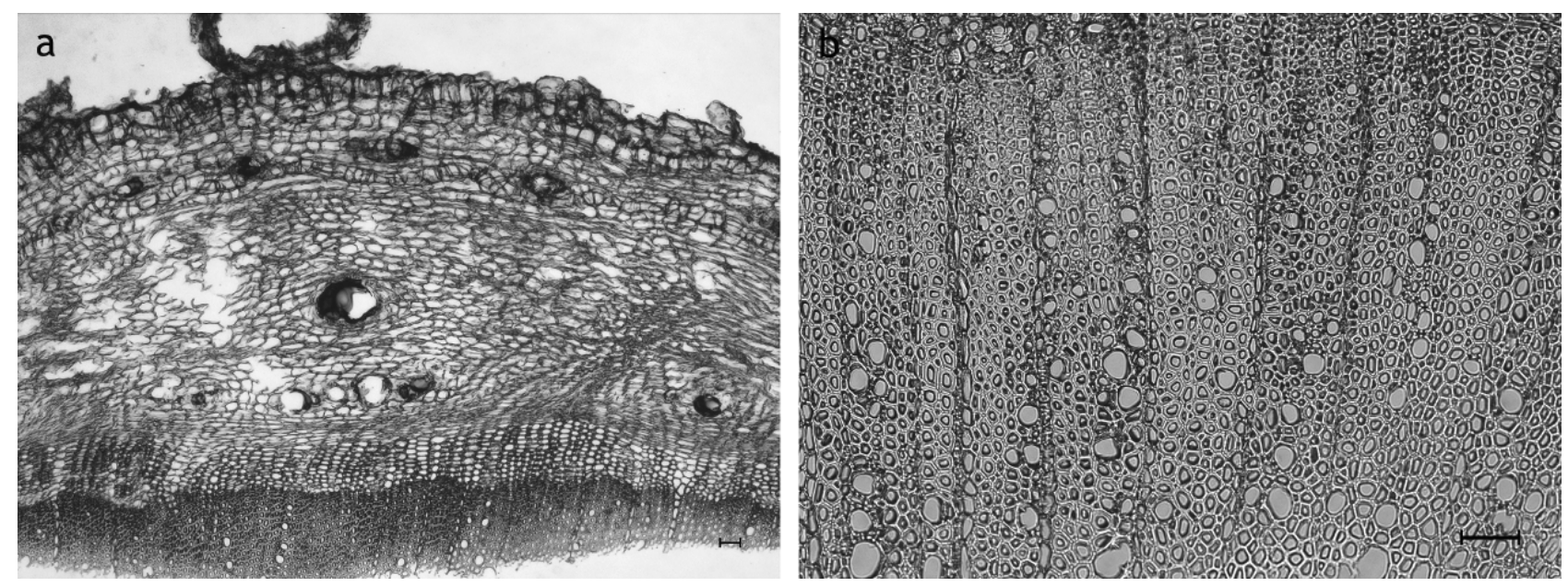

Fig. 3. Carlina vulgaris root: a: overview showing distinct endodermal resin ducts and secretory ducts of the type SD2b in the secondary phloem; $b$ : xylem dominated by fibers and with dispersed vessels, biseriate medullary rays in regular arrangement; a, b: transverse sections; scale bars are $50 \mu \mathrm{m}$

Arctium lappa L. and A. tomentosum Mill. (fig. 4)

The following description applies to both examined species:

Secondary root: broad phellem thin-walled - cortex lost in course of rhytidome formation; endodermal resin ducts lost together with the cortex; secondary phloem broad, but of lesser radial extension than the vascular cylinder, possibly with fibers arranged in bundles; secondary xylem mostly with vessels in rows - in the center single-rowed, in the outer part multiple-rowed, often combined with fibers, mainly reticulate, also weakly bordered up to $89 \mu \mathrm{m}$ ( $A$. lappa) / $125 \mu \mathrm{m}$ ( A. tomentosum) in diameter; medullary rays multiseriate, unlignified; cells of medullary rays often obliterating and easily ripping apart; pith missing; sclereids, crystalloids missing; secretory ducts besides endodermal resin ducts missing;

The early loss of the cortex with its endodermal resin ducts deprives the genus Arctium of a character otherwise valuable for taxonomic comparisons with taxa outside of the Cardueae. 

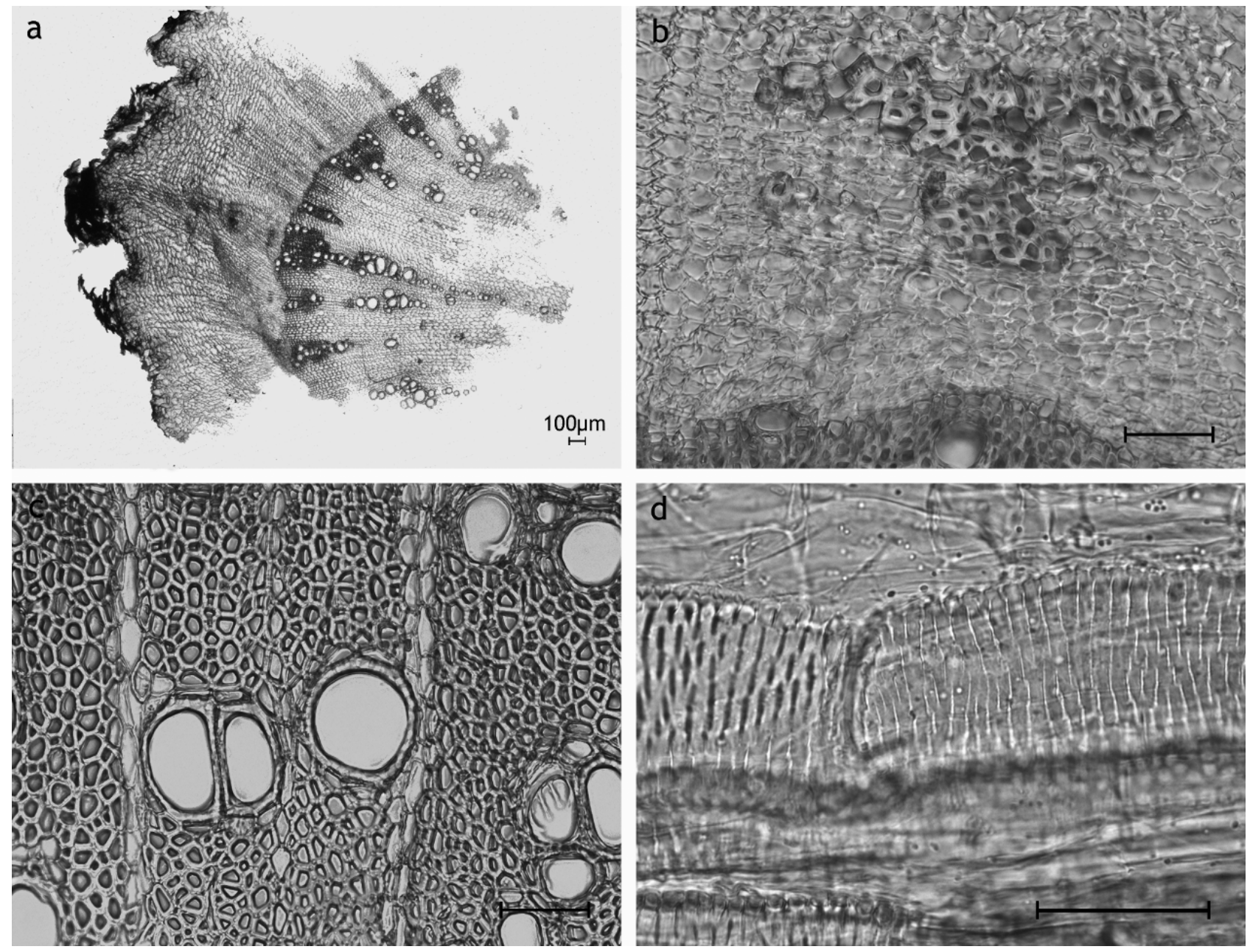

Fig. 4. Arctium lappa root: a: Overview demonstrating the extension and arrangement of tissues: the secondary xylem is the most expanded component followed in extension by the secondary phloem; cortex lost in course of rhytidome formation; xylem dominated by unlignified parenchymatous cells, vessels arranged in rows; $b$ : secondary phloem with sclereids and fibers arranged in bundles ; c: xylem with fibers and with dispersed vessels, medullary rays in regular arrangement; $d$ : reticulate vessels; a-c: transverse sections; $d$ : longitudinal section; scale bars are $50 \mu \mathrm{m}$

\section{Onopordum acanthium L. (fig. 5)}

Secondary root: cork thin-walled, sometimes with crystalloids; small cortex enduring; distinct endodermis with endodermal resin ducts usually up to 6 surrounding cells at maximum; secondary phloem usually broader than cortex, but of lesser radial extension than the vascular cylinder, with fibers single and arranged in bundles; secondary xylem with fibers alternating with parenchymatous cells, vessels dispersed, strongly bordered, up to $150 \mu \mathrm{m}$ in diameter; multiseriate medullary rays multiseriate; pith missing; sclereids missing; secretory ducts beside endodermal resin ducts missing; 

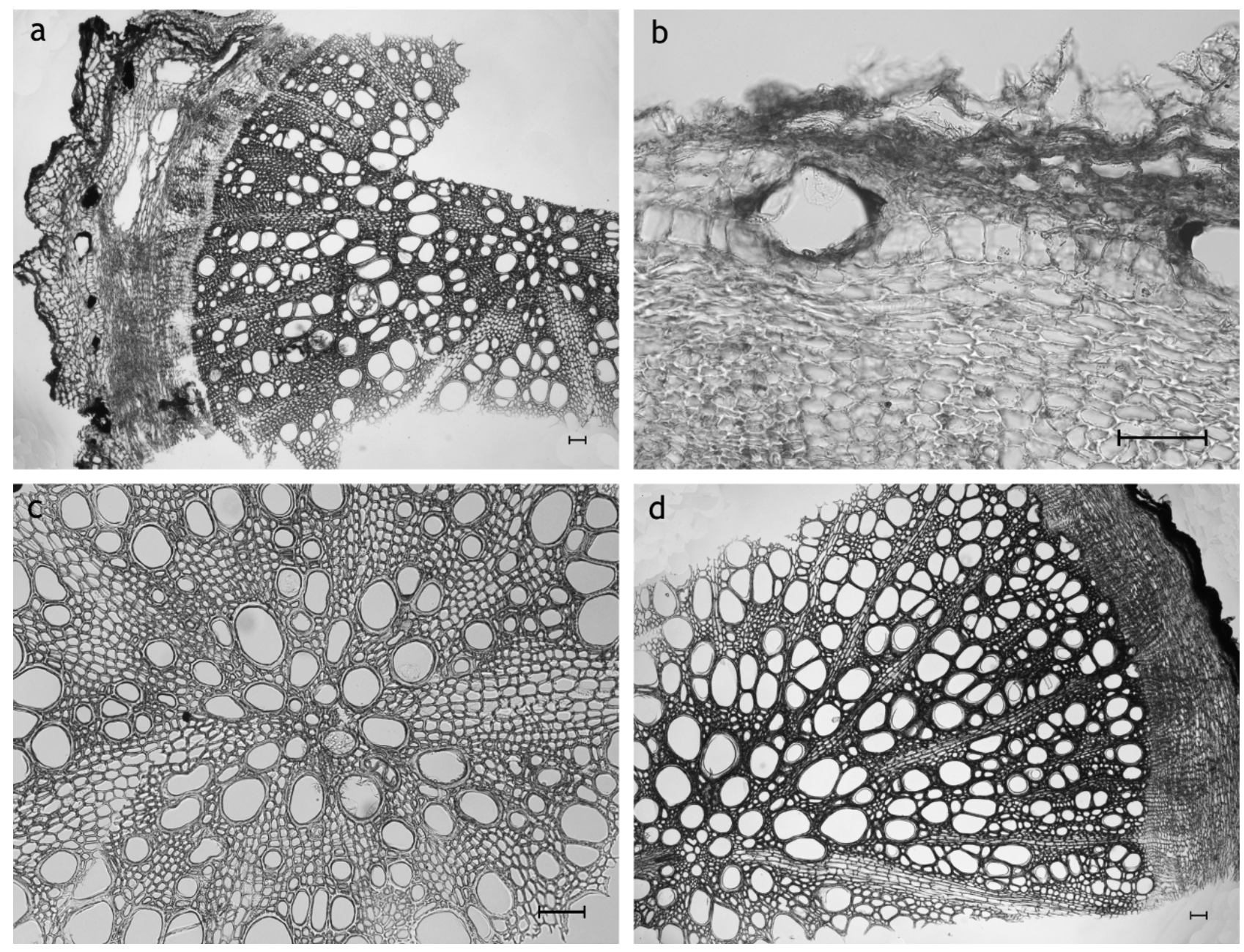

Fig. 5. Onopordum acanthium root: a: Overview showing the extension and arrangement of tissues: the secondary xylem is the most expanded component followed in extension by the secondary phloem; cortex enduring with endodermal resin ducts; vascular cylinder with multiseriate medullary rays (from left to right); b: Distinct endodermis with endodermal resin ducts usually up to 6 surrounding cells at maximum; c Vascular cylinder with multiseriate medullary rays, numerous dispersed vessels, fibers; d: Silybum marianum root: cortex lost, secondary phloem broader than cortex but of far lesser radial extension than the vascular cylinder; a-d: transverse sections; scale bars are $50 \mu \mathrm{m}$

The root anatomy of Silybum marianum resembles that of 0 . acanthium. A distinction among these species may be possible with proceeding secondary growth: rhytidome formation within $S$. marianum versus maintenance of a durable cortex with well visible endodermal resin ducts in $O$. acanthium. The root anatomy of Cnicus benedictus and $O$. acanthium is similar. The diameter of the vessels may serve as the only discriminative character available (C. benedictus: $<100 \mu \mathrm{m}$, O. acanthium up to $150 \mu \mathrm{m}$ ) with the value of this feature questionable 
Rhaponticum scariosum Lam. (fig. 6)

Secondary root: cork thin-walled; cortex enduring; endodermal resin ducts; secondary phloem dominant, often almost comparable in extension to the vascular cylinder, with fibers arranged in bundles possible, secretory ducts type SD2 located in fascicular position between the phloem rays, circularly arranged, forming a triangle; secondary xylem with bundles of fibers in conjunction with vessels, more or less circularly arranged relative to the centre of the xylem, vessels reticulate, up to $120 \mu \mathrm{m}$ in diameter, with secretory ducts type SD2 located in fascicular position in the secondary xylem between the medullary rays; medullary rays broad, multiseriate, unlignified; pith missing; sclereids, crystalloids missing;
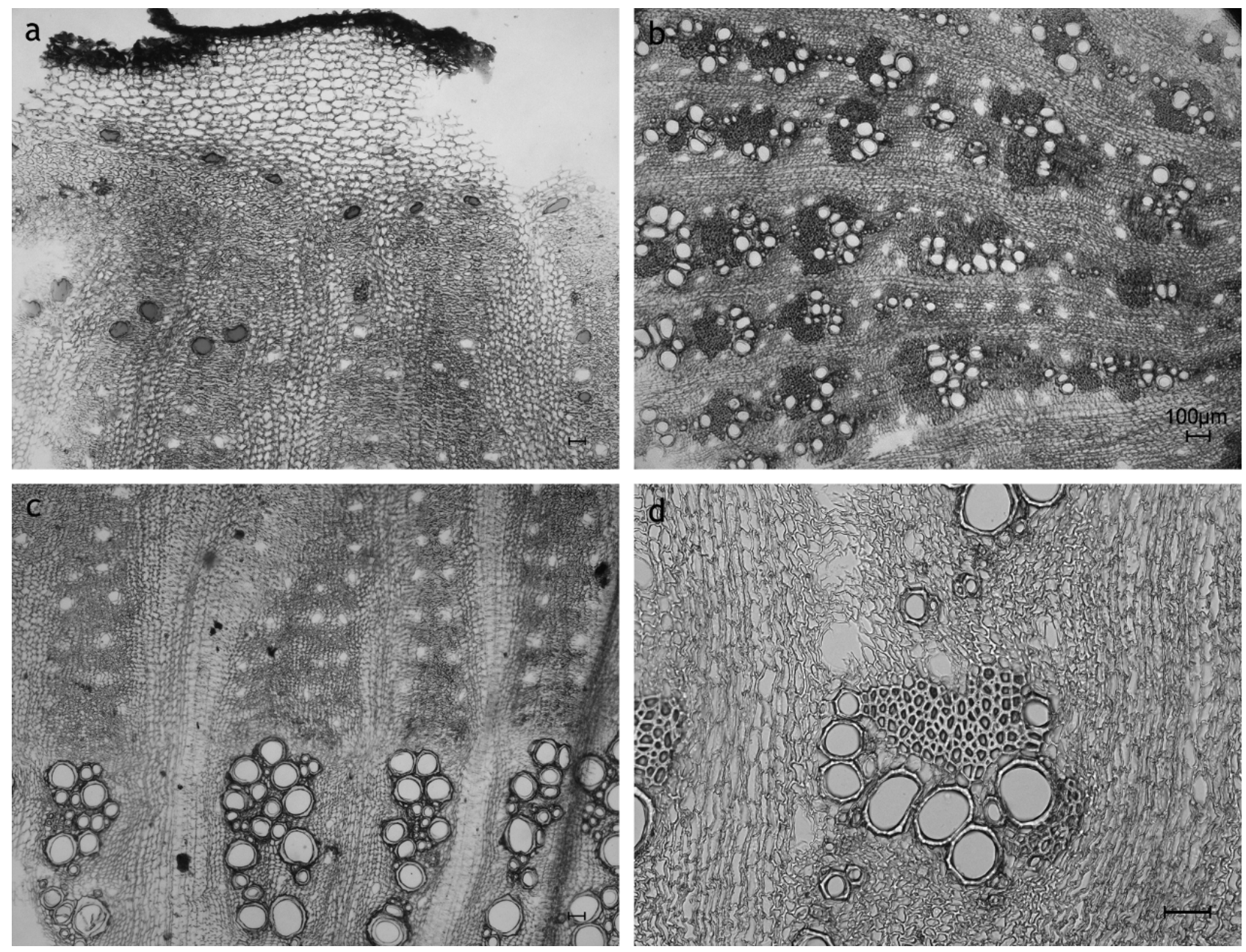

Fig. 6. Rhaponticum scariosum root: a: enduring cortex with endodermal resin ducts, SD2 in secondary phloem between phloem rays; b: overview showing the extension of the vascular cylinder with vessels in groups more or less circularly arranged relative to the centre of the xylem, multiseriate medullary rays; c: secretory ducts type SD2 arranged in fascicular position between phloem rays of the secondary phloem and the medullary rays of the secondary xylem; $d$ : group of vessels and fibers of the secondary xylem, secretory ducts SD2; a-d: transverse sections; scale bars are $50 \mu \mathrm{m}$ 
The anatomy of $R$. scariosum clearly differs from all other species examined in this study based on the arrangement of the secretory ducts. Although the roots develop ducts both within the secondary phloem and the secondary xylem like Carlina acaulis, in $R$. scariosum ducts are found in fascicular position, i.e. between the medullary rays. In contrast, ducts occur within the medullary in all other taxa examined.

\section{Carduus sp. and Cirsium sp.}

Carduus defloratus, C. personata, Cirsium arvense, C. vulgare and C. erisithales are close relatives of the medicinally used species described above. These species are representatives of the subtribe Carduinae (just like Onopordum acanthium and Arctium spp.) and studied given their potential occurrence as adulterations.

The characters of highest value for the discrimination of Carduus and Cirsium (except Cirsium erisithales) from their medicinally used relatives is the exhibition of sclereids (fig. 7). Cirsium erisithales, can be distinguished instead based on its rhizome, which replaces the root developed in the other studied species (fig. 8).
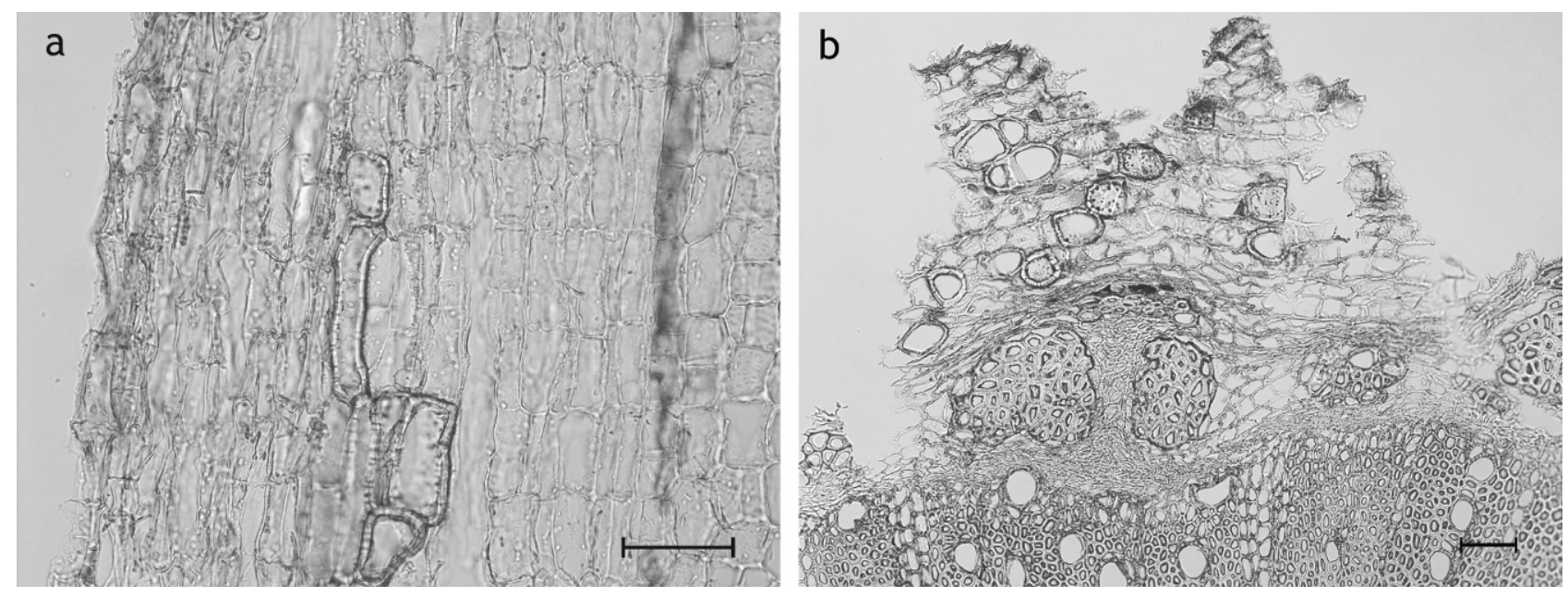

Fig. 7. Cirsium arvense root: sclereids (as an important discriminative character) developed within the cortex; a: longitudinal section; b: transverse sections; scale bars are $50 \mu \mathrm{m}$

\section{Centaurea sp.}

The three species of the genus Centaurea investigated in this study $-C$. jacea, $C$. cyanus and $C$. scabiosa - can be well distinguished from each other based on secretory structures [12]:

Centaurea jacea is characterised by sclereids regularly appearing in conjunction with intercellular spaces filled by various substances secreted by the surrounding cells.

In C. scabiosa, large secretory ducts with lysigenous development, beside others, can be observed in the secondary phloem in fascicular position. Both mentioned secretory ducts are missing in C. cyanus. 

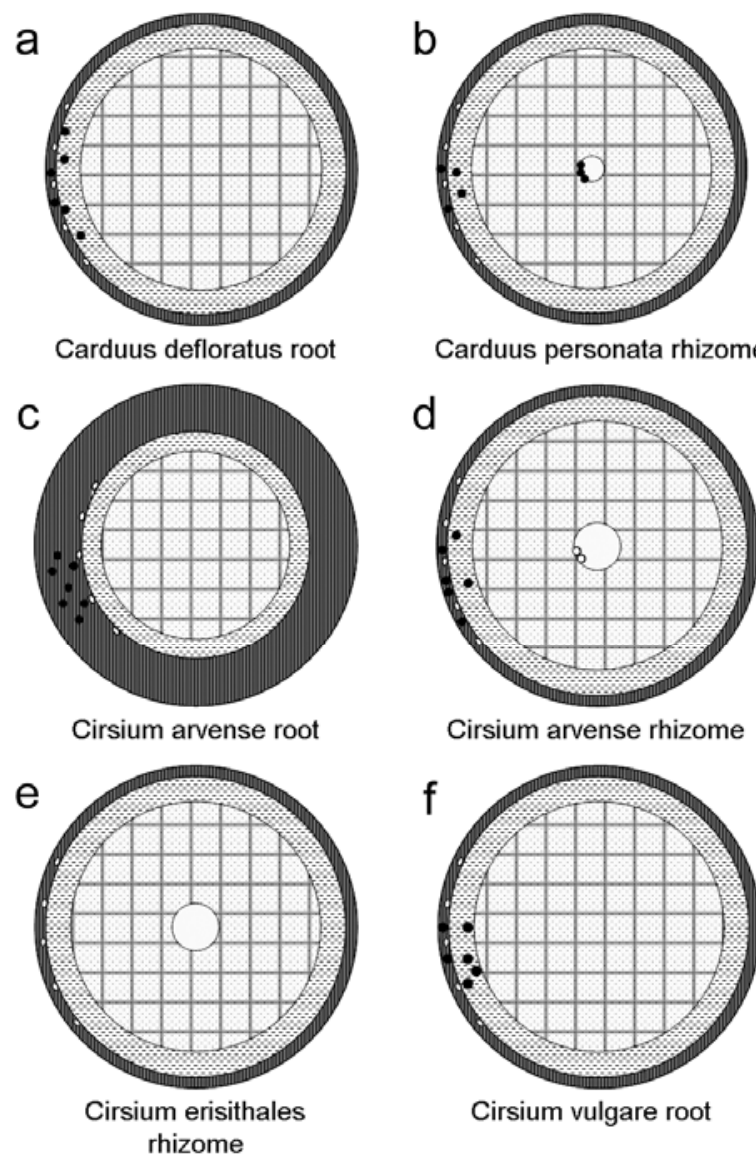

Carduus personata rhizome

d
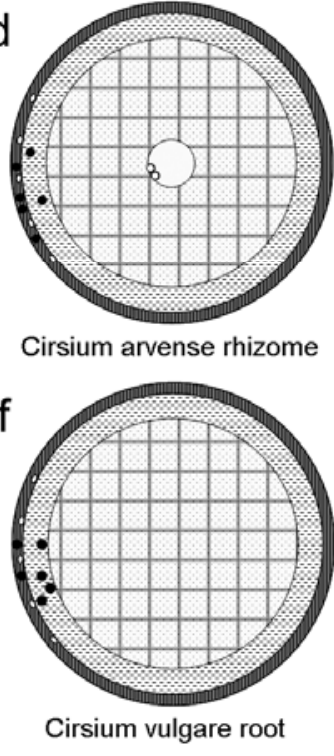

a: Carduus defloratus:

Secondary root: sclereids in cortex and sec. phloem, endoSDs lost together with the cortex in course of rhytidome formation; SDs besides endoSDs missing;

b: Carduus personata:

Rhizome with secondary growth: sclereids in cortex, secondary phloem and as transition between vascular bundles and pith; endoSDs or remnants of them visible; SDs besides endoSDs missing;

$c, d$ : Cirsium arvense:

allorhizous: taproot with long part of rhizome; stoloniferous plant - spreading building rhizomes;

Secondary root (c): sclereids in cortex (large intercellular spaces - aerenchyma) and secondary phloem; endoSDs regularly arranged; SDs besides endoSDs missing;

Rhizome with secondary growth (d): sclereids in cortex and secondary phloem; endoSDs lost lost together with the suberizing of the cortex; SDs at the border between vascular bundle and pith;

e: Cirsium erisithales:

Rhizome with secondary growth: endoSDs lost together with the cortex due to rhytidome formation; sclereids missing; SDs besides the endoSDs missing;

\section{f: Cirsium vulgare:}

Secondary root: sclereids in cortex and secondary phloem; endoSDs lost together with the cortex due to rhytidome formation; SDs beside endoSDs missing;

Fig. 8. Schematic view of Carduus sp. and Cirsium sp. (transverse section): small ellipses mark the position of the enodermal resin ducts (endoSDs) of the cortex and the ducts of type SD2, black points represent the sclereids

\section{Discussion}

The diameter of vessels is a parameter frequently used for the identification of medicinal drugs [e.g. 13]. Our studies, however, demonstrated that this character may largely vary, aside from the age and development of a root, even within one plant. Therefore, the root part taken for respective analyses should be standardized. This appears highly important, even so most studies did not define the exact spatial localisation and developmental stage of the analysed root sample [13]. In case of cut roots as common with commercially traded 
drugs, the use of not-standardized values may be misleading. Furthermore, varying preparation methods may influence the dimension of the vessels.

Discrimination between most of the examined species proofed possible based on the observed diversity and differentiation of the various anatomical features analysed. A summary of the root anatomy as seen in transverse sections is presented for these species in figures 9 and 10 . This overview is intended to provide a taxonomic key.
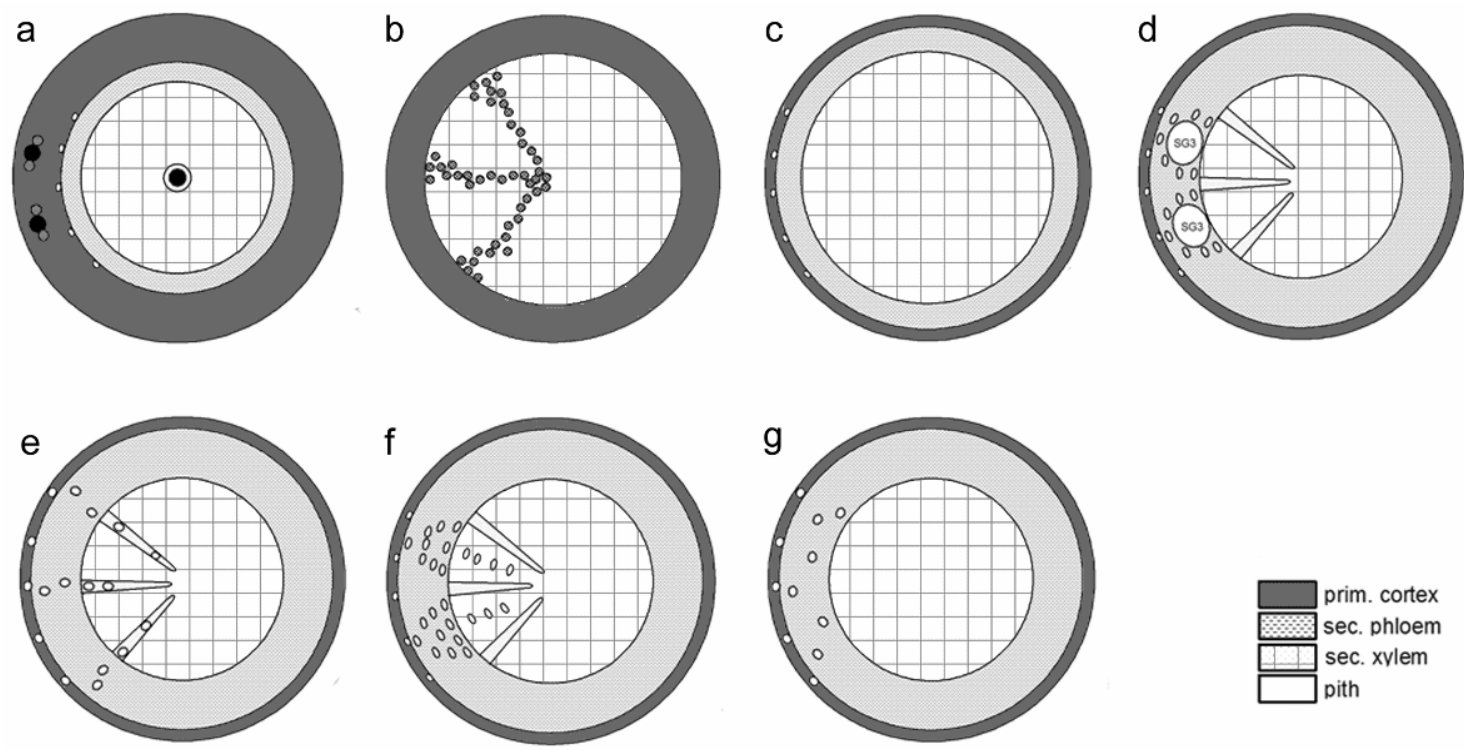

Fig. 9. Schematic view of the various roots studied: small ellipses mark the position of the endodermal resin ducts of the cortex and the ducts of type SD2; a: black points represent the sclereids in conjunction with secretory ducts (grey dots), b: points represent the vessels (b); a: Centaurea jacea; b: Arctium lappa, A. tomentosum; c: Onopordum acanthium, Silybum marianum, Cnicus benedictus; d: Centaurea scabiosa; e: Carlina acaulis; f: Rhaponticum scariosum; g: Carlina vulgaris, Centaurea cyanus;

Strikingly, all species of the genera Cirsium and Carduus as well as Centaurea jacea can be easily identified in medicinal drugs by the unique possession of rhizomes or sclereids. The other taxa can be distinguished based on the presence or absence, type (according to [12]) and spatial location of secretory structures.

Interestingly, the anatomy of several species may vary widely within a single genus (Centaurea sp., Carlina sp.) or, in contrast, be indifferent and of no discriminative value as in the case of the genus Arctium. In addition, species of different genera may be quite similar in root anatomy (Onopordum acanthium, Cnicus benedictus, Silybum marianum).

The discrimination between the two examined representatives of the genus Carlina, $C$. acaulis and $C$. vulgaris, is easily possible based on anatomical features: The endodermal resin ducts of the enduring cortex of $C$. vulgaris, and $C$. acaulis. are clearly distinct in size. In conjunction with the endodermis - usually visible even in roots showing secondary growth - this feature well characterizes these species. The C1:C2 quotient of the epithelial 
cells of the secretory ducts occurring in the secondary phloem as well as their spatial position provide other good discriminative features. The domination of fibers over few vessels in the secondary xylem, vessel diameter (up to $60 \mu \mathrm{m}$; about half the value observed in C. acaulis), and biseriate medullary rays with ducts missing are additional characters distinguishing the medically inconsiderable species from its valuable relative. Finally, the absence of fibers in the secondary phloem and of crystalline needles may be used for differentiation.

1 Rhizome Cirsium arvense, Cirsium erisithales (fig. 12)

- Taproot.

2 Sclereids present. Cirsium sp., Carduus sp. (fig. 12), Centaurea jacea (fig. 8a)

- Sclereids absent.

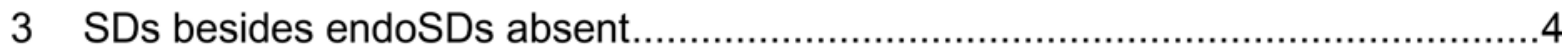

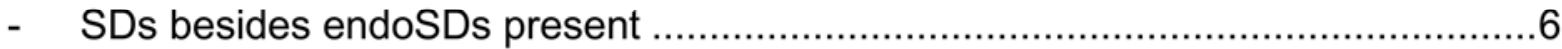

4 Cortex lost with secondary growth, secondary xylem with vessels arranged in rows..................................................Arctium lappa, A. tomentosum (fig. 8b)

- Cortex remains but becomes part of rhytidome........... Silybum marianum (fig. 8c)

- Cortex enduring with distinct endodermis.

5 Diameter of the largest vessels $(1.5 \mathrm{~cm}$ below hypocotyle $)<100 \mu \mathrm{m}$.

Cnicus benedictus (fig. 8c)

- Diameter of the largest vessels $(1.5 \mathrm{~cm}$ below hypocotyle $)>100 \mu \mathrm{m}$. Onopordum acanthium (fig. 8c)

6 Secretory structures of type SD3 present Centaurea scabiosa (fig. 8d)

- Secretory structures of type SD2 present, SD3 absent.

7 SD2 within secondary phloem and secondary xylem ..........................................

- SD2 within secondary phloem

8 SD2 interfascicular positioned Carlina acaulis (fig. 8e)

- SD2 fascicular positioned. 9

9 SD2 in secondary phloem with no typical pattern.......Rhaponticum carthamoides

- SD2 in secondary phloem forming a characteristic pattern ....R. scariosum (fig. 8f)

$10 \mathrm{C} 1: \mathrm{C} 2=1-1.01$

Centaurea cyanus (fig. 8g)

- $\quad \mathrm{C} 1: \mathrm{C} 2=0.48-0.62$ Carlina vulgaris (fig. $8 \mathrm{~g}$ )

Fig. 10. Key of the subterranean organs of the species examined in this study; * Data concerning R. carthamoides is based on Łotocka \& Geszprych [27]

Centaurea cyanus, C. jacea and C. scabiosa differed from each other in secretory duct type (fig. 8). 
According to Łotocka \& Geszprych [27] an anatomical differentiation between $R$. carthamoides and $R$. scariosum seems possible. The conspicuous arrangement of the secretory ducts within the secondary phloem, arranged in regular circles around the centre thereby forming together with the phloem rays a kind of triangular pattern, however,, is not described in that study. Rhaponticum scariosum appears to develop a much more extensive secondary phloem than the medicinally applied species.

This study on the anatomy of several roots and rhizomes of the Cardueae reveal considerable among-species variation. Important features of discriminative value are the arrangement of principal tissues as observed in transverse section of roots and rhizomes, the tissue-dependent occurrence of fibers and sclereids as well as of various types of secretory ducts. The different duct types [12] provide a particularly valuable character for taxonomic discrimination if the type of surrounding tissue and their position relative to prominent anatomical elements such as vascular bundles is taken into account. Certainly, the arrangement and diameter of vessels and the appearance of medullary rays in the secondary xylem must not be forgotten. However, the largest diameter of vessels though can be only considered a reliable taxonomically informative character if applied to root parts standardized in terms of developmental age and spatial position.

In summary, an identification of most investigated taxa used in medicine proofed possible based on various extracted anatomical characters. Further studies into the root anatomy using a broader and more diverse taxonomic sample have to verify the feasibility of microscopic techniques for the identification of medicinally used genera and species of the Asteraceae.

\section{Experimental}

The plant material comprised of 16 Cardueae species naturally occurring in Austria. Species were chosen respectively to their use in medicine (Carlina acaulis, Carlina vulgaris, Arctium lappa, Arctium tomentosum, Onopordum acanthium,) and their role as possible adulterations (Rhaponticum scariosum, Carduus defloratus, Carduus personata, Cirsium arvense, Cirsium vulgare, Cirsium erisithales, Silybum marianum, Centaurea jacea, Centaurea scabiosa, Centaurea cyanus and Cnicus benedictus.). To guarantee full development of the roots, the plants were collected during or following antheses. A list of the studied species including the collection history is provided in Table1 (taxonomy follows Fischer et al., 2008 [31]). Vouchers available for all studied species are deposited in the herbarium of the Department of Pharmacognosy, University of Vienna (WUP). The plant material was taxonomically determined using floristic treatments covering the sampled geographic areas [31-33].

In order to include modificative effects of the environment (e.g. influence of the soil) on root anatomy, each species was collected from different locations if possible.

Anatomical analysis: The roots were examined by means of light microscopy. For preparation, a traditional method of our department was used: After boiling in water for about 10 minutes to soften the tissues, the roots were embedded in $96 \%$ ethanol for dehydration. Transverse and longitudinal sections were obtained by free hand sectioning about $1.5 \mathrm{~cm}$ below the hypocotyle as this position proofed to be the furthest developed region, thus providing the most information about the anatomy. The resulting sections 
were embedded in few drops of a solution of chloral hydrate $(60 \%$ in water) and examined using a Nikon Optiphot-2 light microscope equipped with a Samsung Digimax V50 Digital Camera.

Tab. 1. List of species examined in this study (accessions are taxonomically arranged following the current systematic concept provided in [31]); AUT: Austria, GER: Germany, ITA: Italy, POL: Poland, SLK: Slovakia, LIE: Liechtenstein; Plant material collected by Elisabeth Fritz (EF), Christoph Dobeš (CD), Silvia Fialova (SF), Werner Lahner (WL), Günther Stadler (GS)

\begin{tabular}{|c|c|c|}
\hline \multirow{2}{*}{$\begin{array}{l}\text { Genus } \\
\text { Carlina }\end{array}$} & Species & Location of collection \\
\hline & C. acaulis $\mathrm{L}$. & $\begin{array}{l}\text { AUT, Vienna, EF } \\
\text { GER, Baden-Württemberg, Schwäbische Alb, } \\
\text { Hohenack, Nr. } 652 \text { (WUP) } \\
\text { Samples of a commercially traded product } \\
\text { (Kottas Pharma, sample number 1881, 1882) } \\
\text { POL, Gutkowo / Olsztyn, EF }\end{array}$ \\
\hline$\overline{\text { Arctium }}$ & $\begin{array}{l}\text { A. lappa L. } \\
\text { A. tomentosum Mill. }\end{array}$ & $\begin{array}{l}\text { AUT, Vienna, Donauinsel, EF } \\
\text {-, Lower Austria, Traiskirchen, EF }\end{array}$ \\
\hline Carduus & $\begin{array}{l}\text { C. defloratus } \mathrm{L} \text {. } \\
\text { C. personata (L.) Jacq }\end{array}$ & $\begin{array}{l}\text {-, Lower Austria, Gippel, CD } \\
\text {-, Lower Austria, Araburg, EF } \\
\text {-, Styria, Schneealpe, EF }\end{array}$ \\
\hline Cirsium & $\begin{array}{l}\text { C. arvense (L.) Scop. } \\
\text { C. vulgare (Savi) Ten. } \\
\text { C. erisithales (Jacq.) } \\
\text { Scop. }\end{array}$ & $\begin{array}{l}\text { SLK, Modra, Tochova Chata, SF } \\
\text { AUT, Vienna, EF } \\
\text { POL, Gutkowo / Olsztyn, EF } \\
\text { AUT, Styria, Schneealpe, EF }\end{array}$ \\
\hline Onopordum & O. acanthium L. & $\begin{array}{l}\text { AUT, Lower Austria, Buchberg, WL } \\
\text { ITA, Southern Tyrol, Vinschgau, CD }\end{array}$ \\
\hline Silybum & $\begin{array}{l}\text { S. marianum (L.) } \\
\text { Gaertn. }\end{array}$ & $\begin{array}{l}\text { AUT, Lower Austria, Buchberg, EL } \\
\text { SLK, Bratislava, Botanical Garden, SF }\end{array}$ \\
\hline Rhaponticum & רR. scariosum Lam. & LIE, GS \\
\hline Centaurea & $\begin{array}{l}\text { C. cyanus L. } \\
\text { (= Cyanus segetum } \\
\text { Hill., Fischer et al.) }\end{array}$ & $\begin{array}{l}\text { Austria, Karnabrunn, CD } \\
\text {-, Vienna, EF } \\
\text {-, Vienna, JS } \\
\text { Poland, Gutkowo, Olsztyn, EF } \\
\text { Switzerland, Graubünden, Lavin, CD } \\
\text { Austria, Vienna, EF } \\
\text { Germany, Baden-Württemberg, Kronau, CD } \\
\text { Poland, Mazury, Zabie, EF }\end{array}$ \\
\hline Cnicus & C. benedictus L. & $\begin{array}{l}\text { Botanical Garden of the Department of } \\
\text { Pharmacognosy, University of Vienna }\end{array}$ \\
\hline
\end{tabular}

\section{Acknowledgements}

We'd like to thank our colleagues Christoph Dobeš, Silvia Fialova, Werner Lahner and Günther Stadler for their help with the collection of plant material. 


\section{Supporting Information}

Detailed descriptions and pictures of all species mentioned in the text are available in the online version (Format: PDF, Size: ca. 5.3 MB): http://dx.doi.org/10.3797/scipharm.1010-05.

\section{Authors' Statement}

Competing Interests

The authors declare no conflict of interest.

\section{References}

[1] Jeffrey C.

Compositae.

In: Kubitzki K, ed. The Families and Genera of Vascular Plants. VIII Flowering Plants-Eudicots.

Berlin Heidelberg: Springer Verlag, 2007: 61-77.

[2] Col MA.

Recherches sur l'appareil sécréteur interne des composées.

Journal de Botanique. 1903; 17: 252-318.

[3] Col MA.

Recherches sur l'appareil sécréteur interne des composées (Suite). Journal de Botanique. 1904; 18: 110-174.

[4] Van Tieghem M.

Sur la situation de l'appareil sécréteur dans les composées.

B Soc Bot Fr. 1883; 30: 310-313.

[5] Van Tieghem M.

Sur la situation de l'appareil sécréteur dans la racine des composées.

B Soc Bot Fr. 1884; 31: 112-116.

[6] Ragonese AM.

Canales secretores en los organos vegetativos de Eupatorium inulaefolium H.B.K. (Compositae).

Acta Farm Bonaerense. 1988; 7: 161-168.

[7] Hayashi H.A., Appezzato-da-Gloria B.

Anatomy of the underground system in Vernonia grandiflora Less. and V. brevifolia Less.

(Asteraceae).

Braz Arch Biol Technol. 2007; 50: 979-988.

doi:10.1590/S1516-89132007000700009

[8] Melo-de-Pinna G, Menezes N.

Meristematic endodermis and secretory structures in adventitious roots of Richterago Kuntze

(Mutisieae-Asteraceae).

Rev Bras Bot. 2003; 26: 1-10.

doi:10.1590/S0100-84042003000100002

[9] Appezzato-da-Gloria B, Hayashi AH, Cury G, Soares MKM, Rocha R.

Occurrence of secretory structures in underground systems of seven Asteraceae species.

Bot J Linn Soc. 2008; 157: 789-796.

doi:10.1111/j.1095-8339.2008.00823.x

[10] Cury G., Appezzato-da-Glória B.

Internal secretory spaces in thickened underground systems of Asteraceae species.

Aust J Bot. 2009; 57: 229-239.

doi:10.1071/BT08139 
[11] Fritz E, Saukel J.

Interxylary cork of Saussurea discolor DC. and S. pygmaea Spreng. (Asteraceae).

Biologia; In print.

[12] Fritz E, Saukel J.

Secretory structures of the Cardueae and their value for discrimination.

In prep.

[13] Länger $R$.

Orientierende Untersuchungen zur Wurzelanatomie einiger Cichorieaceen.

Sci Pharm. 1990; 58: 417-422.

[14] Fritz E.

PhD-Thesis.

Unpublished, 2010.

[15] Bock H.

Kräutterbuch.

Strassburg: Wilhelm Christian Glaser, 1539, reprint 1630.

[16] Fuchs L.

New Kreuterbuch.

Basel. 1543.

[17] Frohne D.

Heilpflanzenlexikon.

Stuttgart: Wissenschaftliche Verlagsgesellschaft mbH. 2006.

[18] Länger R, Kubelka W.

Phytokodex. Pflanzliche Arzneispezialitäten in Österreich 2001/2002.

Gablitz: Krause\&Pachernegg GmbH. 2001.

[19] Gerlach S, Saukel J, Kubelka W.

Pflanzen in der österreichischen Volksmedizin - die „Volksmed-Datenbank“.

Sci Pharm. 2006; 74 (Suppl 1): S36.

doi:10.3797/scipharm.oephg.19.OP

[20] Berendes J.

Des Pedanius Dioskurides aus Anazarbos Arzneimittellehre in fünf Büchern.

Stuttgart, 1902.

[21] Kardošová A, Ebringerováa A, Alföldia J, Nosál'ováb G, Fraňováb S, Hříbalovác V.

A biologically active fructan from the roots of Arctium lappa L., var. Herkules.

Int J Biol Macromol. 2003; 33: 135-140.

doi:10.1016/S0141-8130(03)00079-5

[22] Lonicerus A.

Kreuterbuch.

Grünwald / München: Kölbl. 1679, reprint 1962.

[23] Madaus G. (1938).

Lehrbuch der Biologischen Heilmittel.

Leipzig: Olms Verlag. 1938.

[24] Dos Santos AC, Baggio CH, Freitas CS, Lepieszynski J, Mayer B, Twardowschy A, Missau FC, dos Santos EP, Pizzolatti MG, Marques MC. Gastroprotective activity of the chloroform extract of the roots from Arctium lappa L.

J Pharm Pharmacol. 2008; 60: 795-801.

doi:10.1211/jpp.60.6.0016

[25] Lin SC, Chung TC, Lin CC, Ueng TH, Lin YH, Lin SY, Wang LY.

Hepatoprotective Effects of Arctium Lappa on Carbon Tetrachloride- and Acetaminophen-Induced Liver Damage.

Am J Chin Med. 2000; 163-173.

doi:10.1142/S0192415X00000210 
[26] Mattioli PA.

New Kreuterbuch.

1563.

[27] Łotocka B, Geszprych A.

Anatomy of the vegetative organs and secretory structures of Rhaponticum carthamoides

(Asteraceae).

Bot J Linn Soc. 2004; 144: 207-233.

doi:10.1111/j.1095-8339.2003.00251.x

[28] Kokoska L, Janovska D.

Chemistry and pharmacology of Rhaponticum carthamoides: A review.

Phytochemistry. 2009; 70: 842-855.

doi:10.1016/j.phytochem.2009.04.008

[29] Machatschek M.

Nahrhafte Landschaft: Ampfer, Kümmel, Wildspargel, Rapunzelgemüse.

3rd ed., Wien: Böhlau Verlag. 2007.

[30] Susanna A, Garcia-Jacas N.

Tribe Cardueae Cass. (1819).

In: Kubitzki K, eds. The Families and Genera of Vascular Plants. VIII Flowering Plants-Eudicots.

Berlin Heidelberg: Springer Verlag, 2007. 123-146.

[31] Fischer MA, Oswald K, Adler W. (2008).

Exkursionsflora für Österreich, Liechtenstein und Südtirol. 3rd ed.

Austria: OÖ Landesmuseen, Land Oberösterreich. 2008.

[32] Pawłowskiego B, Jasiewicza A.

Flora Polska TOM XIII

Warszawa: Polska Akademia Nauk. 1972.

[33] Szafer W, Kulczyński S, Pawłowski B.

Rośliny Polskie.

4th ed. Warszawa: Panstwowe Wydawnictwo Naukowe. 1976. 